\title{
MINAT BRAIN GAIN MAHASISWA RANTAU ASAL SUMATERA DI FAKULTAS-FAKULTAS AGROKOMPLEKS UNIVERSITAS PADJADJARAN
}

\author{
BRAIN GAIN INTEREST IN MIGRATION STUDENTS FROM SUMATRA \\ IN AGROCOMPLEX FACULTIES OF PADJADJARAN UNIVERSITY
}

\author{
Elfa Dela Rahmanisa*, Iwan Setiawan \\ Program Studi Agribisnis Fakultas Pertanian Universitas Padjadjaran \\ J1. Raya Bandung Sumedang Km. 21 \\ *E-mail: elfadela.rahmanisa@gmail.com \\ (Diterima 14-07-2020; Diterima 26-07-2020)
}

\begin{abstract}
ABSTRAK
Minat pemuda dalam menjadi pelaku muda agribisnis cenderung rendah, namun demikian perlu pengkajian lebih lanjut khususnya bagi mahasiswa di fakultas agrokompleks Unpad. Minat merupakan perasaan pada diri seseorang untuk mengikuti suatu kegiatan sebagai dasar terhadap suatu pekerjaan. Terdapat empat faktor yang mempengaruhi minat mahasiswa, yaitu: (1) dorongan dalam diri individu; (2) motif sosial; (3) faktor emosional; dan (4) motif ekonomi. Penelitian ini bertujuan untuk menjelaskan minat brain gain mahasiswa rantau agrokompleks dan menganalisis faktor-faktor yang mempengaruhi minat brain gain. Penelitian ini merupakan penelitian kuantitatif dengan metode survei. Analisis yang digunakan adalah uji regresi linear berganda. Hasil penelitian menunjukkan, minat brain gain pada mahasiswa rantau tergolong tinggi pada tahapan interest. Berdasarkan uji-t faktor yang mempengaruhi minat mahasiswa aktif asal Sumatera di fakultasfakultas agrokompleks Unpad adalah faktor dorongan dalam diri individu.
\end{abstract}

Kata kunci: brain gain, mahasiswa rantau, minat, agrokompleks

\begin{abstract}
Youth interest in becoming young agribusiness actors tends to below, however, it needs further study especially for students in the Unpad agro complex faculty. Interest is a feeling in someone to follow activity as a basis for a job. Four factors affect student interest, namely: (1) encouragement in individuals; (2) social motives; (3) emotional factors; and (4) economic motives. This study aims to explain the interest in the brain gain of agro complex migration students and to analyze the factors that influence the brain gain interest. This research is quantitative research with a survey method. The analysis used is multiple linear regression test. The results showed that interest in brain gain in overseas students was classified as high at the interest stage. Based on the t-test, the factors that influence the interest of active students from Sumatra in Unpad agro complex faculties are encouragement factors in individuals.
\end{abstract}

Keywords: brain gain, migration student, interest, agro complex

\section{PENDAHULUAN}

Pertanian secara luas terdiri atas lima sektor, yaitu tanaman pangan, perkebunan, peternakan, perikanan, dan kehutanan. Keberlanjutan pembangunan pertanian dapat dijaga melalui lima sektor pertanian ini dengan metode yang tepat. Salah satu metodenya yaitu dengan berorientasi pada bisnis pertanian atau agribisnis (Saragih, 2010).

Pembangunan merupakan suatu usaha perubahan yang dilakukan secara 
terencana untuk meningkatkan kesejahteraan kehidupan masyarakat. Hal ini sejalan dengan kesepakatan pembangunan global, yaitu Sustainable Development Goals (SDGs). Tujuan SDGs nomor dua eksplisit "mengakhiri kelaparan, mencapai ketahanan pangan serta nutrisi yang lebih baik dan mendukung pertanian berkelanjutan".

Upaya strategis dalam peningkatan kualitas SDM pertanian nasional diperlukan karena Indonesia mengalami krisis regenerasi petani. Data Sutas 2018 menunjukkan terjadi penurunan jumlah petani yang berusia produktif dari 53 persen menjadi 43,3 persen, kemudian sebaliknya terjadi peningkatan petani yang berusia 55 tahun ke atas dari 23,4 persen menjadi 31,2 persen. Sebaran rumah tangga usaha petani di seluruh provinsi kawasan Sumatera membentuk pengelompokan umur petani yang berlaku umum.

Meskipun tidak terjadi regenerasi petani yang baik, masih terdapat pemuda yang memiliki kesadaran kepada pertanian. Salah satu buktinya yaitu mahasiswa yang mengambil jurusan pertanian (Agrokompleks). Perlu diperhatikan mahasiswa yang mencari pendidikan jauh dari daerah asal dan berkaitan dengan agrokompleks. Salah satu data perguruan tinggi di Jawa Barat, yaitu Universitas Padjadjaran (2016) menyebutkan sebanyak 788 mahasiswa baru yang diterima berasal dari pulau Sumatera.

Termaktub pada makna brain gain yaitu kembalinya atau membalik SDMSDM terdidik dan berkeahlian dari perantauan ke daerah asal, hal ini sejalan dengan tujuan setelah merantau yaitu kembalinya perantau ke daerah asal. Pada mahasiswa sudah seharusnya minat brain gain ditanamkan saat masih berstatus mahasiswa aktif. Hal ini akan membawa dampak pada pembangunan daerah asal terutama di bidang pertanian.

Minat merupakan suatu keinginan yang erat hubungannya dengan perhatian kemudian menimbulkan kehendak dari seseorang yang akan memusatkan seluruh aktivitas fisik maupun psikis diri ke arah yang sedang diamati (Pratiwi, 2015). Minat berdasarkan aspeknya terdiri atas aspek kognitif (mengenal), aspek afektif (perasaan), dan aspek psikomotorik (kehendak) (Hurlock, 1995). Setiawan (2015) menegaskan generasi muda yang terlatih dan terdidik untuk mau kembali dan berusaha secara rasional di negara atau di daerah asalnya (brain gain) merupakan kunci untuk mengubah nasib, 
citra diri, keberhasilan dan keberlanjutan (regenerasi) petani.

Implementasi konsep brain gain internal penting bagi negara yang memiliki ketimpangan pembangunan yang tinggi (perkotaan-pedesaan) atau wilayah yang berbentuk pulau-pulau dengan konsentrasi pembangunan ada pada segelintir pulau (Setiawan, 2018). Oleh karena itu, brain gain ditawarkan sebagai salah satu solusi untuk memecahkan masalah ketimpangan pembangunan pertanian dan kesenjangan SDM terdidik di Indonesia melalui regenerasi pelaku muda pertanian.

Berdasarkan minat pemuda dalam menjadi generasi muda pertanian cenderung rendah, hal ini perlu dilakukan pengkajian lebih lanjut khususnya bagi mahasiswa di fakultas-fakultas agrokompleks Unpad akan minat terhadap brain gain. Penelitian ini bertujuan untuk menjelaskan minat brain gain pada mahasiswa asal Sumatera di fakultas-fakultas agrokompleks Unpad dan menganalisis faktor-faktor yang mempengaruhi minat mahasiswa rantau untuk melakukan brain gain.

\section{METODE PENELITIAN}

Penelitian ini menggunakan desain kuantitatif dengan metode survei.
Penelitian dilakukan di fakultas-fakultas agrokompleks Universitas Padjadjaran, yaitu fakultas pertanian, fakultas peternakan, fakultas perikanan dan kelautan, dan fakultas teknologi industri pertanian selama dua bulan, mulai 31 Maret 2020 sampai 31 Mei 2020. Terdapat dua jenis data yang dikumpulkan yaitu data primer dan data sekunder. Data primer diperoleh dari informan, yakni mahasiswa asal Sumatera di fakultas-fakultas agrokompleks yang berjumlah 74 orang dipilih menggunakan rumus slovin dengan error $10 \%$ dengan teknik sampel berstrata proposional. Data sekunder berupa studi literatur penelitian terkait. Uji instrumen penelitian menggunakan uji validitas dan uji reabilitas. Data-data yang dikumpulkan dilakukan uji asumsi klasik dan uji regresi linear berganda.

\section{HASIL DAN PEMBAHASAN}

Minat adalah suatu hal yang bersumber dari perasaan yang berupa kecendrungan terhadap suatu hal sehingga menimbulkan perbuatanperbuatan atau kegiatan tertentu (Hidayat et al, 2013). Minat dapat diukur berdasarkan aspek-aspek yang akan dilakukan seseorang (Kanuk, 2007), yaitu (1) Tertarik untuk mencari informasi 
tentang objek; (2) Mempertimbangkan untuk melakukan; (3) tertarik untuk mencoba; (4) Ingin mengetahui brain gain lebih dalam; dan (5) Ingin memiliki minat brain gain. Berdasarkan hasil tabulasi data penelitian dari 74 mahasiswa aspek minat yang ada pada mahasiswa rantau di fakultas-fakultas agrokompleks yaitu ingin memiliki minat brain gain, artinya mahasiswa akan mengambil keputusan terhadap brain gain dan membentuk niat untuk kembali ke daerah asal. Kategori mahasiswa rantau yang ingin memiliki minat brain gain termasuk tinggi.

Tingkatan minat menurut Ferdinand (2012) dapat dikelompokkan menjadi: (1) minat transaksional; (2) minat referensial; (3) minat preferensial; dan (4) minat eksploratif. Berdasarkan hasil tabulasi data penelitian menunjukkan $\quad 65,41 \% \quad$ minat transaksional artinya mahasiswa memiliki minat yang tinggi untuk melakukan brain gain berdasarkan yang diinginkannya, $63,51 \%$ minat referensial artinya mahasiswa yang telah memiliki minat brain gain akan memberi saran kepada orang terdekatnya untuk melakukan brain gain, 56,76\% minat preferensial artinya prioritas utama untuk melakukan brain gain pada mahasiswa ada pada kategori sedang, dan $66,49 \%$ minat eksploratif artinya mahasiswa yang sudah memiliki minat terhadap brain gain akan mencari dukungan terhadap brain gain di daerah asalnya sesuai dengan bidang yang diambil yang akan menghasilkan sebuah prestasi.

Menurut Kotler (2008), terdapat empat tahapan minat, yaitu attention, interest, desire, dan action. Hasil tertinggi pada penelitian menunjukkan mahasiswa rantau asal Sumatera di fakultas-fakultas agrokompleks Unpad berada pada tahap interest artinya mahasiswa mulai tertarik untuk melakukan brain gain setalah ditawarkan dan mendapat informasi rinci tentang peluang brain gain di daerah asal. Minat mahasiswa rantau terhadap brain gain (kembali ke daerah asal) berdasarkan beberapa indikator tergolong tinggi. Hal ini diperkuat dengan rincian minat mahasiswa berdasarkan karakteristik pada Tabel 1. Tabel ini menunjukkan bahwa minat mahasiswa rantau melakukan brain gain termasuk ke dalam kategori sedang sampai tinggi, artinya mahasiswa rantau memiliki minat melakukan brain gain di bidang agrokompleks. 
Tabel 1. Tingkatan Minat berdasarkan Karakteristik Mahasiswa

\begin{tabular}{l|c|c|c|c}
\hline Karakteristik & n & \multicolumn{3}{|c}{ Minat } \\
\cline { 3 - 5 } & & Rendah & Sedang & Tinggi \\
\hline Jenis Kelamin & & & & \\
- Laki-laki & 33 & 0 & 14 & 19 \\
- Perempuan & 41 & 1 & 21 & 19 \\
Usia & & & & \\
- <20 & 9 & 0 & 5 & 4 \\
- 20-22 & 64 & 1 & 30 & 33 \\
- 22 & 1 & 0 & 0 & 1 \\
Fakultas & & & & \\
- FAPERTA & 28 & 0 & 15 & 13 \\
- FAPET & 13 & 0 & 6 & 7 \\
- FPIK & 16 & 1 & 3 & 12 \\
- FTIP & 17 & 0 & 11 & 6 \\
Angkatan & & & & \\
- 2016 & 31 & 0 & 14 & 17 \\
- 2017 & 27 & 1 & 13 & 13 \\
- 2018 & 16 & 0 & 8 & 8 \\
Pekerjaan Ortu & & & & \\
- Pertanian & 18 & 0 & 7 & 11 \\
- Non-pertanian & 56 & 1 & 28 & 27 \\
\hline Sumber: Data
\end{tabular}

Sumber: Data diolah, 2020

Tingkatan minat berdasarkan jenis kelamin menunjukkan, minat mahasiswa laki-laki melakukan brain gain dengan minat mahasiswa perempuan melakukan brain gain sama-sama tinggi (50\%). Tingkat minat berdasarkan usia mahasiswa yang sebagian besar berumur 20-22 tahun, yakni 1 mahasiswa $(1,3 \%)$ memiliki minat rendah, 30 mahasiswa (40,5\%) memiliki minat sedang, dan 33 mahasiswa $(44,6 \%)$ memiliki minat tinggi untuk melakukan brain gain. Dengan demikian, pada umumnya mahasiswa dengan usia 20-22 tahun memiliki minat sedang sampai tinggi untuk melakukan brain gain. Tabel 2 merupakan rincian dari tingkatan minat berdasarkan karakteristik mahasiswa yang aktif asal Sumatera di fakultasfakultas agrokompleks yaitu angkatan 2016, 2017 dan 2018.

Tabel 2. Inbox Mahasiswa dengan Minat Brain Gain Tinggi

\begin{tabular}{|c|c|}
\hline Petani & mingi \\
\hline 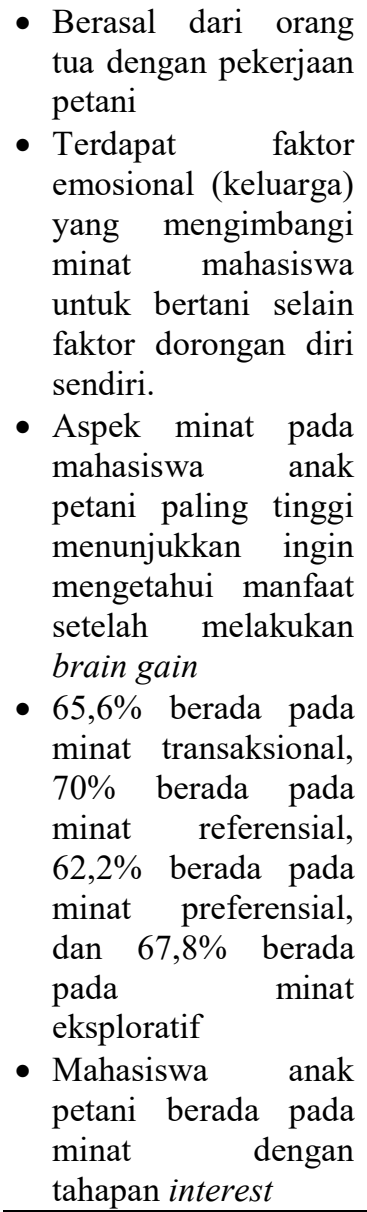 & $\begin{array}{l}\text { - } \text { Berasal dari orang } \\
\text { tua dengan pekerjaan } \\
\text { non-pertanian } \\
\text { - Minat bertani } \\
\text { muncul dari } \\
\text { dorongan dalam diri } \\
\text { sendiri dan berani } \\
\text { dalam mengambil } \\
\text { risiko di daerah asal } \\
\text { - Aspek minat tinggi } \\
\text { pada mahasiswa ini } \\
\text { menunjukkan ingin } \\
\text { memiliki minat } \\
\text { brain gain minat } \\
\text { - 65,4\% } \% \text { transaksional, } 63,5 \% \\
\text { minat referensial, } \\
\text { 56,8\% minat } \\
\text { preferensial, } 66,5 \% \\
\text { minat eksploratif } \\
\text { - Mahasiswa lainnya } \\
\text { berada pada minat } \\
\text { dengan tahapan } \\
\text { interest }\end{array}$ \\
\hline
\end{tabular}

Sumber: Data diolah, 2020

Tingkatan minat berdasarkan jenis kelamin menunjukkan, minat mahasiswa laki-laki melakukan brain gain dengan minat mahasiswa perempuan melakukan brain gain sama-sama tinggi (50\%). Tingkat minat berdasarkan usia mahasiswa yang sebagian besar berumur 20-22 tahun, yakni 1 mahasiswa $(1,3 \%)$ 
memiliki minat rendah, 30 mahasiswa (40,5\%) memiliki minat sedang, dan 33 mahasiswa $(44,6 \%)$ memiliki minat tinggi untuk melakukan brain gain. Dengan demikian, pada umumnya mahasiswa dengan usia 20-22 tahun memiliki minat sedang sampai tinggi untuk melakukan brain gain. Tabel 28 merupakan rincian dari tingkatan minat berdasarkan karakteristik mahasiswa yang aktif asal Sumatera di Fakultasfakultas agrokompleks yaitu angkatan 2016, 2017 dan 2018.

Urutan fakultas dengan minat tinggi terhadap brain gain pada mahasiswa, yaitu fakultas perikanan dan kelautan (FPIK), fakultas peternakan (FAPET), fakultas pertanian (FAPERTA), dan fakultas teknologi industri pertanian (FTIP). Berdasarkan stereotip mahasiswa FTIP ada pada bidang industri, mahasiswa memilih bekerja di daerah industri dibandingkan dengan melakukan brain gain. Berdasarkan tahun masuk kuliah, mahasiswa 2016 memiliki minat tinggi untuk melakukan brain gain dibandingkan dengan mahasiswa 2017 dan mahasiswa 2018. Hal ini didukung dengan mahasiswa 2016 yang sudah berada pada tahun akhir perkuliahan sudah memiliki sikap atau keputusan untuk kembali ke daerah asal.
Berdasarkan pekerjaan orang tua, minat brain gain pada mahasiswa menunjukkan mahasiswa dengan orangtua yang berprofesi sebagai petani memiliki minat lebih tinggi dibandingkan dengan mahasiswa yang orangtuanya bekerja di bidang non-pertanian. Artinya pada mahasiswa anak petani akan terjadi regenerasi petani berdasarkan garis keluarga. Berdasarkan data dari Sekretariat Unpad (2019), yang dikomparasi dengan nama mahasiswa responden penelitian menunjukkan mahasiswa yang orangtuanya petani didominasi berasal dari Sumatera Barat dan Sumatera Utara. Hal ini sejalan dengan jumlah mahasiswa aktif Unpad tahun 2019 yang menunjukkan 153 mahasiswa berasal dari Sumatera Utara.

Tingkatan minat mahasiswa berdasarkan pendapatan orangtua. Tabel 3 menunjukkan bahwa $35 \quad(47,4 \%)$ mahasiswa dari 74 mahasiswa memiliki keluarga dengan pendapatan $\geq \mathrm{Rp}$ 4.000.001 (kategori tinggi). Terdapat 1 mahasiswa $(1,4 \%)$ memiliki minat rendah, 17 mahasiswa (23\%) memiliki minat sedang, serta 17 mahasiswa (23\%) memiliki minat tinggi. Dengan demikian, mahasiswa dengan pendapatan keluarga $\geq \operatorname{Rp} 4.000 .001$ memiliki keinginan tinggi untuk melakukan brain gain. 
Sebaran uang saku mahasiswa dominan pada kisaran Rp $600.001-1.500 .000$ (kategori cukup), 56,1\% memiliki minat tinggi untuk melakukan brain gain. $78,4 \%$ mahasiswa yang menerima uang saku dari orangtua, hanya $46 \%$ yang memiliki minat tinggi terhadap brain gain.

\begin{tabular}{|c|c|c|c|c|}
\hline 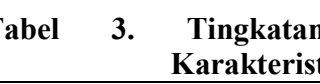 & & $\begin{array}{l}\text { inat I } \\
\text { hasiswa }\end{array}$ & Berdasarl & xan \\
\hline & & & Minat & \\
\hline Karakteristik & $\mathbf{n}$ & Rendah & Sedang & Tinggi \\
\hline Pendapatan Orangtua & & & & \\
\hline$-\leq 2.000 .000$ & 14 & 0 & 7 & 7 \\
\hline$-2.000 .001-4.000 .000$ & 25 & 0 & 11 & 14 \\
\hline$-\geq 4.000 .001$ & 35 & 1 & 17 & 17 \\
\hline Sumber Uang Saku & & & & \\
\hline - Orang tua & 58 & 1 & 30 & 27 \\
\hline - Beasiswa & 13 & 0 & 5 & 8 \\
\hline - Bekerja & 2 & 0 & 0 & 2 \\
\hline - Lainnya (saudara) & 1 & 0 & 0 & 1 \\
\hline Uang Saku Bulanan & & & & \\
\hline$-\leq 600.000$ & 7 & 1 & 2 & 4 \\
\hline$-\overline{6} 00.001-1.500 .000$ & 41 & 0 & 18 & 23 \\
\hline$-1.500 .001-2.000 .000$ & 19 & 0 & 10 & 9 \\
\hline$-2.000 .000-3.000 .000$ & 7 & 0 & 5 & 2 \\
\hline Besar Keluarga & & & & \\
\hline$-<4$ orang & 23 & 1 & 11 & 11 \\
\hline - 5-6 orang & 41 & 0 & 19 & 22 \\
\hline$->7$ orang & 10 & 0 & 5 & 5 \\
\hline
\end{tabular}

Tingkat minat berdasarkan besar keluarga pada Tabel 3 menunjukkan 41 mahasiswa $(55,4 \%)$ dari 74 mahasiswa memiliki keluarga dengan jumlah tanggungan 5-6 orang (keluarga sedang). Terdapat 19 mahasiswa $(25,7 \%)$ memiliki minat sedang dan 22 mahasiswa $(29,7 \%)$ memiliki minat tinggi. Dengan demikian mahasiswa dengan tipe keluarga sedang/ideal (5-6 orang) memiliki minat tinggi untuk melakukan brain gain.

\section{Uji Normalitas}

Berdasarkan Uji Skewness Kurtosis menunjukkan $\mathrm{P}$ value $>0,05$ artinya data berdistribusi normal pada tabel (prob>chi2). Nilai signifikansi variabel $\mathrm{Y}$ yaitu $0,8146>0,05$, nilai signifikansi variabel $\mathrm{X} 1$ yaitu $0,7840>0,05$, nilai signifikansi variabel X2 yaitu $0,3619>$ 0,05 , nilai signifikansi variabel $\mathrm{X} 3$ yaitu $0,2146>0,05$, dan nilai nignifikansi variabel $\mathrm{X} 4$ yaitu $0,3859>0,05$.

\section{Uji Multikolinieritas}

Hasil uji multikolinieritas menunjukkan bahwa semua variabel menghasilkan nilai tolerance $>0,10$ dan nilai VIF $5,03<10$. Artinya variabel bebas pada penelitian ini tidak terjadi multikolinieritas dalam model regresi. Dengan demikian variabel dorongan individu, motif sosial, emosional, dan motif ekonomi dapat digunakan sebagai variabel independen sebagai prediktor yang tidak bias.

\section{Uji Heteroskadaditas}

Berdasarkan uji heteroskadasitas pada tabel 32 diatas menujukkan nilai $\mathrm{p}$ value $>0,05$ yaitu pada prob $>$ chi2 $(0,3580>0,05)$ yang berarti variabel bebas dalam penelitian ini tidak terjadi 
heteroskadasitas dan dapat dilanjutkan ke tahap pengujian regresi.

\section{Uji Signifikansi Secara Simultan (Uji}

F)

Berdasarkan hasil olahan data menggunakan $\quad$ STATA $\quad 14.0$ menunjukkan, Prob $>\mathrm{F}=0,000$ artinya $0,000<0,05(\mathrm{P}$ value $<\alpha)$. H0 ditolak dan H1 diterima artinya terdapat pengaruh secara simultan yang signifikant antara $\mathrm{X} 1, \mathrm{X} 2, \mathrm{X} 3$, dan $\mathrm{X} 4$ terhadap minat brain gain pada mahasiswa rantau asal Sumatera di fakultas-fakultas Agrokompleks.

\section{Uji Signifikansi Secara Parsial (Uji t)}

1) Berdasarkan hasil olah data STATA, variabel X1 yaitu dorongan individu menghasilkan $(\mathrm{P}$ value $)<0,05$ yaitu $0,000<0,05$ maka H0 ditolak dan H1 diterima, artinya ada pengaruh yang signifikan secara parsial antara dorongan individu dengan minat brain gain mahasiswa rantau.

2) Berdasarkan hasil olah data STATA, variabel X2 yaitu motif sosial menghasilkan $(\mathrm{P}$ value $)>0,05$ yaitu 0,549>0,05 maka H1 ditolak dan H0 diterima, artinya tidak ada pengaruh yang signifikan secara parsial antara motif sosial dengan minat brain gain mahasiswa rantau.

3) Berdasarkan hasil olah data STATA, variabel X3 yaitu faktor emosional menghasilkan $(\mathrm{P}$ value $)>0,05$ yaitu 0,499 > 0,05 maka H1 ditolak dan H0 diterima, artinya tidak ada pengaruh yang signifikan secara parsial antara faktor emosional dengan minat brain gain mahasiswa rantau.

4) Berdasarkan hasil olah data STATA, variabel X4 yaitu motif ekonomi menghasilkan $(\mathrm{P}$ value $)>0,05$ yaitu 0,222 > 0,05 maka H1 ditolak dan H0 diterima, artinya tidak ada pengaruh yang signifikan secara parsial antara motif ekonomi dengan minat brain gain mahasiswa rantau.

\section{Uji Determinasi $\left(\mathbf{R}^{\mathbf{2}}\right)$}

Model yang terbentuk dari variabel independen (X1, X2, X3, dan X4) mampu menjelaskan variabel dependen yaitu minat brain gain pada mahasiswa rantau asal Sumatera di fakultas-fakultas agrokompleks sebesar $68,1 \%$; sedangkan sisanya $31,9 \%$ dijelaskan oleh variabel di luar model $(\varepsilon)$.

Berdasarkan hasil perhitungan regresi menyatakan faktor dorongan individu (swakarsa) berpengaruh signifikan secara parsial terhadap minat 
brain gain. Hasil regresi ini didukung dengan beberapa tanggapan mahasiswa, (1) Mahasiswa agrokompleks secara pribadi memiliki kesadaran akan kebutuhan SDM intelektual pada bidang agrokompleks yang terus meningkat di daerah asal. (2) Pengetahuan agrokompleks yang mahasiswa dapat selama perkuliahan menumbuhkan keinginan untuk berkecimpung di bidang agrokompleks di daerah asal. (3) Mahasiswa memiliki pandangan terhadap pembangunan daerah asal sangat penting. (4) Kembali ke daerah asal memberi semangat mahasiswa untuk mambangun sektor agrokompleks. (5) Mahasiswa yang ingin mengetahui brain gain di bidang agrokompleks adalah pilihan karier mahasiswa di masa depan. (6) Mahasiswa memiliki motivasi untuk pembangunan daerah asal dengan melakukan brain gain. (7) Mahasiswa yang berkecimpung di bidang agrokompleks karena ingin melaksanakan pengabdian di daerah asal.

\section{KESIMPULAN DAN SARAN}

Berdasarkan tujuan dan pembahasan, dapat ditarik kesimpulan sebagai berikut: (1) Minat mahasiswa berdasarkan aspek minat yang ada pada mahasiswa rantau di fakultas-fakultas agrokompleks yaitu ingin memiliki minat brain gain. Berdasarkan tingkatan minat menunjukkan $\quad(65,41 \%) \quad$ minat transaksional artinya mahasiswa memiliki minat yang tinggi untuk melakukan brain gain berdasarkan yang diinginkannya, $(63,51 \%)$ minat referensial artinya mahasiswa yang telah memiliki minat brain gain akan memberi saran kepada orang terdekatnya untuk melakukan brain gain, $(56,76 \%)$ minat preferensial artinya prioritas utama untuk melakukan brain gain pada mahasiswa ada pada kategori sedang, dan $(66,49 \%)$ minat eksploratif artinya mahasiswa yang sudah memiliki minat terhadap brain gain akan mencari dukungan terhadap brain gain di daerah asalnya sesuai dengan bidang yang diambil yang akan menghasilkan sebuah prestasi. Berdasarkan tahapan minat pada mahasiswa yaitu berada pada tahap interst $(65,68 \%)$ artinya mahasiswa mulai tertarik untuk melakukan brain gain setalah ditawarkan dan mendapat informasi rinci tentang peluang brain gain di daerah asal. Jika dihubungkan antara minat brain gain dengan karakteristik mahasiswa dapat disimpulkan minat mahasiswa aktif asal Sumatera di fakultas-fakultas agrokomplek Unpad termasuk kedalam kategori sedang sampai tinggi artinya 


\section{MINAT BRAIN GAIN MAHASISWA RANTAU ASAL SUMATERA \\ DI FAKULTAS-FAKULTAS AGROKOMPLEKS UNIVERSITAS PADJADJARAN \\ Elfa Dela Rahmanisa, Iwan Setiawan}

mahasiswa memiliki keinginan atau minat kembali ke daerah asal; (2) faktor dorongan individu, motif sosial, faktor emosional, dan motif ekonomi berpengaruh secara signifikan $(68,1 \%)$ terhadap minat brain gain pada mahasiswa. Namun, secara parsial (sendiri) hanya dorongan individu yang berpengaruh terhadap minat mahasiswa untuk melakukan brain gain. Perlu dilakukan penelitian lebih lanjut untuk melihat aksi mahasiswa yang telah lulus dari perguruan tunggu di daerah asal masing-masing.

Saran terhadap penelitian yang telah dilakukan dan yang akan dilakukan, yaitu: (1) Minat mahasiswa rantau asal Sumatera yang sudah tergolong tinggi untuk melakukan brain gain (kembali ke daerah asal) sebaiknya terus dijaga, melalui peran fakultas dengan melakukan kuliah eksternal bersama alumni-alumni agrokompleks untuk memberikan motivasi dan gambaran kehidupan setelah kuliah. (2) Peran universitas, fakultas, dan himpunan mahasiswa melalui seminar atau workshop tentang brain gain, dapat dilakukan sebagai upaya mengenalkan brain gain di kalangan mahasiswa rantau dengan harapan membuka wawasan dalam pembangunan daerah berdasarkan bidang keilmuan di agrokompleks. (3) Penelitian selanjutnya sebaiknya melakukan metode $\mathrm{RnD}$ untuk melihat aksi mahasiswa yang telah lulus dari perguruan tinggi di daerah asal masing-masing. Selain itu dapat dilakukan pengukuran minat berdasarkan pada peserta seminar tentang brain gain sebagai salah satu langkah memperkenalkan tentang brain gain secara luas.

\section{DAFTAR PUSTAKA}

Badan Pusat Statistika. 2018. Hasil Survei Pertanian Antar Sensus (SUTAS) 2018

Batista, C., Lacuesta, A., \& Vicente, pedro c. 2011. Testing the 'Brain Gain' Hypothesis: Micro Evidence from Cape Verde. Development Economics, 01(005).

Budiati, I. 2014. Implikasi Minat Siswa Dalam Pengelolaan Pertanian Di Wilayah Kecamatan Parongpong. Jurnal Pendidikan Ilmu Sosial, 23(2), 103-107.

Budiman, A. 2000. Teori Pembangunan Dunia Ketiga. Jakarta: Gramedia Pustaka Utama.

Bungin, B. 2013. Metodologi Penelitian Sosial dan Ekonomi. Jakarta: Kencana.

Coenen, F. H. J. M. (2005). The social dimension of regional sustainable development planning.

Faiz, P. M. 2007. Brain Drain Dan Sumber Daya Manusia Indonesia: Studi Analisa terhadap Reversed Brain Drain di India.

Heriyanto. 2008. Brain Drain, Masalah Besar Bagi Negara Berkembang.

Kone, Z. L. 2017. Brain Drain, Gain, and Circulation. 
Kupets, O. 2011. Brain Gain Or Brain Waste? The Performance Of Return Labor Migrants In The Ukrainian Labor Market.

Lien, D., \& Wang, Y. 2005. Brain drain or brain gain: A revisit. Popul Econ, 18, 153-163.

Marleni, Lusi. 2016. Faktor-faktor yang mempengaruhi minat belajar siswa kelas VIII SMP Negeri 1 Bankinang. Jurnal Pendidikan Matematika. 1(1), 149-159.

Panurat, S. M. 2014. Faktor - Faktor Yang Mempengaruhi Minat Petani Berusahatani Padi Di Desa Sendangan Kecamatan Kakas Kabupaten Minahasa. Jurnal Sosial Ekonomi, 4(50).

Pratiwi, N. K. 2015. Pengaruh Tingkat Pendidikan, Perhatian Orang Tua, Dan Minat Belajar Siswa Terhadap Prestasi Belajar Bahasa Indonesia Siswa Smk Kesehatan Di Kota Tangerang. Jurnal Pujangga, 1(2), 75-105.

Saefuloh, A. A. 2012. Kebijakan Reverse Brain : Mengapa Penting Dan Alternatif Pendekatan. Ekonomi \& Kebijakan Publik, 3(1), 109-124.

Saefuloh, A. A. 2012. Motif Kerja Generasi Muda Di Bidang Pertanian: Studi Fenomenologi Tentang Motif Kerja di Bidang Pertanian pada Kelompok Pemuda Tani di Kota Batu. Jurnal Ekonomi dan Kebijakan Publik, 3(1), 109124.
Saragih, B. 2010. Agricultural Industries. IPB Press

Setiawan, I. 2015. Perkembangan Kemandirian Pelaku Brain Gain Sebagai Alternatif Inovasi Regenerasi di Dataran Tinggi Jawa Barat.

Setiawan, I., Nugraha, A., \& Heryanto, M. A. 2018. Proses Brain Gain Pelaku Muda Agribisnis Di Dataran Tinggi Jawa Barat. Social Economic of Agriculture, 7(2), 8598.

Setiawan, I., Sumardjo, Satria, A., \& Tjitropranoto, P. 2016. Studi Potensi Brain Gain Sebagai Inovasi Regenerasi Pelaku Agribisnis Di Dataran Tinggi Cianjur. Sosiohumaniora, 18(1), 47-54.

Sholik, M. I., Rosyid, F., Mufa'idah, K., Agustina, T., \& Ashari, U. R. 2016. Merantau Sebagai Budaya (Eksplorasi Sistem Sosial Masyarakat Pulau Bawean). Cakrawala, 10(2), 143-153.

Simbolon, N. 2014. Faktor-faktor yang mempengaruhi Minat Belajar Peserta Didik. Elementary School Journal Pgsd Fip Unimed 1(2), 22.

Stark, O. 2005. The new economics of the brain drain.

Susanti, Sartika, Muhammad Hasan, M. Ihsan Said Ahmad, Marhawati. 2018. Faktor-faktor yang Mempengaruhi Minat Mahasiswa Berinvestasi di Galeri Investasi. Makasar: Fakultas Ekonomi. Universitas Negeri Makasar. 